ANALIZA KONKURENTNOSTI BOSNE I HERCEGOVINE U KONTEKSTU PRISTUPNIH PROCESA EU

\title{
ANALYSIS OF THE COMPETITIVENESS OF BOSNIA AND HERZEGOVINA IN THE CONTEXT OF EU ACCESSION PROCESS
}

\section{Sanja Jakovljević}

ZP „Elektrodistribucija“ a. d., Pale, Bosna i Hercegovina

\section{Tatjana Klincov Vujaković}

Univerzitet za poslovne studije, Banja Luka, Bosna i Hercegovina

OMESTE

JEL Category: 011

\begin{abstract}
Apstrakt
lako postoji više definicija pojma konkurentnost, OECD je istu definisao kao sposobnost zemlje da u slobodnim i ravnopravnim tržišnim uslovima proizvodi robe i usluge koje prolaze test međunarodnog tržišta, uz istovremeno povećanje realnog dohotka stanovništva. Ova definicija konkurentnosti jasno ukazuje da pojedinu zemlju možemo smatrati konkurentnom ne samo pod uslovom da ima značajnu ulogu u proizvodnji i plasiranju roba na svjetska tržišta, nego da i građani te zemlje u posmatranom periodu ostvaruju viši životni standard mjeren različitim pokazateljima. Na žalost, nizak životni standard od svega trećine EU28 prosjeka jasno ukazuje da BiH uveliko zaostaje za drugim zemljama u tranziciji koje su prošle ili prolaze proces evropskih integracija. Sa stanovišta ekonomske teorije faktori koji određuju tempo ekonomske konvergencije su početna pozicija, očuvanje makroekonomske stabilnosti $i$ stepen uspješnosti u sprovođenju strukturalnih reformi.

Nakon globalne recesije, svjetsku ekonomiju karakteriše visok nivo nezaposlenosti, slabiji rast produktivnosti, te prigušen ekonomski rast koji i dalje može biti opterećen raznim neizvjesnostima, kao što su geopolitičke tenzije, cijene energenata i promjena kursa valuta. Ovako nastalo stanje je dobilo naziv „nova normala“, tj. novo normalno stanje. Međutim, nedavni razvojni trendovi su obećavajući. Takozvana četvrta industrijska revolucija i novi načini potrošnje poput "ekonomije dijeljenja" mogu dovesti do novog vala inovacija za pokretanje rasta. Takođe, u mnogim zemljama, ekonomske politike

Adresa autora zaduženog za korespodenciju: Sanja Jakovljević su sve više fokusirane na potrebe građana, $i$ ugrađene su u sveukupne društvene ciljeve $i$ strategije razvoja.
\end{abstract}

埄"sanjajakovljevic87@yahoo.com 
Ključne riječi: konkurentnost, makroekonomija, industrija, BDP, izvoz.

\begin{abstract}
Even though there are several definitions of the concept of competitiveness, the OECD has defined it as an ability of a country to produce goods and services that pass the test of international market in the conditions of free and equal market, while increasing the real income of the population. This definition of competitiveness clearly shows that each country can be considered competitive not only under the condition that it has a significant role in the production and marketing of goods on world markets, but also that the citizens of this country in the observed period achieved a higher standard of living, measured by various indicators. Unfortunately, the low living standard of a third of the EU28 average clearly indicates that B\&H lags far behind other transition countries that have undergone or are undergoing the process of European integration. From the standpoint of economic theory, factors determining the pace of economic convergence are a starting position, maintaining macroeconomic stability and the degree of success in implementing structural reforms.

After the global recession, the world economy is characterized by high unemployment, lower productivity growth and subdued economic growth which continues to be burdened by a variety of uncertainties, such as geopolitical tensions, energy prices and changes in foreign currency exchange rates. Thus, the resulting situation was named "new normal", i.e. new normal situation. However, recent development trends are promising. The so-called fourth industrial revolution and new ways of spending such as "sharing economy" could lead to a new wave of innovation to drive growth. Also, in many countries, economic policies are increasingly focused on the needs of citizens, and are embedded in the overall societal objectives and strategies of development.
\end{abstract}

Keywords: competition, macroeconomics, industries, GDP, exports.

\section{EKONOMSKI TRENDOVI U BIH}

Ekonomska integracija se ostvaruje na prostoru koji obuhvata teritorije više država, sa ciljem da se otklone prepreke kretanju, robe, ali i usluga i faktora proizvodnje (Ristić, 2015/2016). BiH je predmet regionalnog pristupa Evropske unije zemljama Zapadnog Balkana kroz proces stabilizacije i pridruživanja, kao i element strategije uslovljavanja iz 1997. godine. Politički dijalog, liberalizacija trgovine, saradnja u području pravosuđa i unutrašnjih poslova, te proces stabilizacije i pridruživanja vodilje su integrisanja $\mathrm{BiH}$ u političku i ekonomsku maticu Unije. Postati država članica EU ne znači samo poštovati pravila i standarde EU, to takođe podrazumijeva da zemlja postane ekonomski pogodna za članstvo kako bi sigurno mogla da iskoristi sve pogodnosti pristupanja EU, a istovremeno da doprinese rastu i prosperitetu privrede EU. Na osnovu iskustva država članica EU u Evropskom semestru, Komisija jača svoju podršku poboljšanju ekonomskog upravljanja i konkurentnosti u zemljama obuhvaćenim procesom proširenja. Ovo bi trebalo da pomogne zemljama obuhvaćenim procesom proširenja da iskoriste potencijal za održivi rast i stvaranje novih radnih mjesta, da bolje isplaniraju i rasporede strukturne reforme i na kraju da ispune ekonomske kriterijume. Bosna i Hercegovina je u ranoj fazi u pogledu približavanja evropskim standardima. Određeni nivo pripremljenosti je postignut u pogledu javnih nabavki i unutrašnjeg tržišta. Potrebni su dalji kontinuirani napori naročito $u$ pogledu pitanja pravde, slobode i sigurnosti, u oblasti konkurencije, industrije i malih i srednjih preduzeća, poljoprivrede, politika životne sredine i klimatskih promjena, energetike i informacionog društva i medija.

\subsection{Kretanje osnovnih ekonomskih indikatora u Bosni i Hercegovini}

lako je realni rast ekonomske aktivnosti $\mathrm{BiH} \mathrm{u}$ odnosu na prethodni kvartal tokom prva dva tromjesečja 2015. iznosio svega $0,7 \%$, rast aktivnosti na godišnjem nivou je bio znatno veći. Najveći dio godišnjeg povećanja je zapravo ostvaren u četvrtom tromjesečju 2014. kada je aktivnost povećana u odnosu na treći kvartal za značajnih 1,6\%. Tako je, uprkos skromnom kvartalnom povećanju u naredna dva tromjesečja, ekonomska aktivnost u prvom kvartalu bila za $2,3 \%$, a u drugom za značajnih $4,4 \%$ veća u odnosu na isti period 2014. godine. Intenziviranje 
godišnjeg rasta $u$ drugom tromjesečju je $u$ najvećoj mjeri bilo posljedica pada BDP-a u istom periodu prethodne godine uslijed obilnih poplava koje su zadesile zemlju.

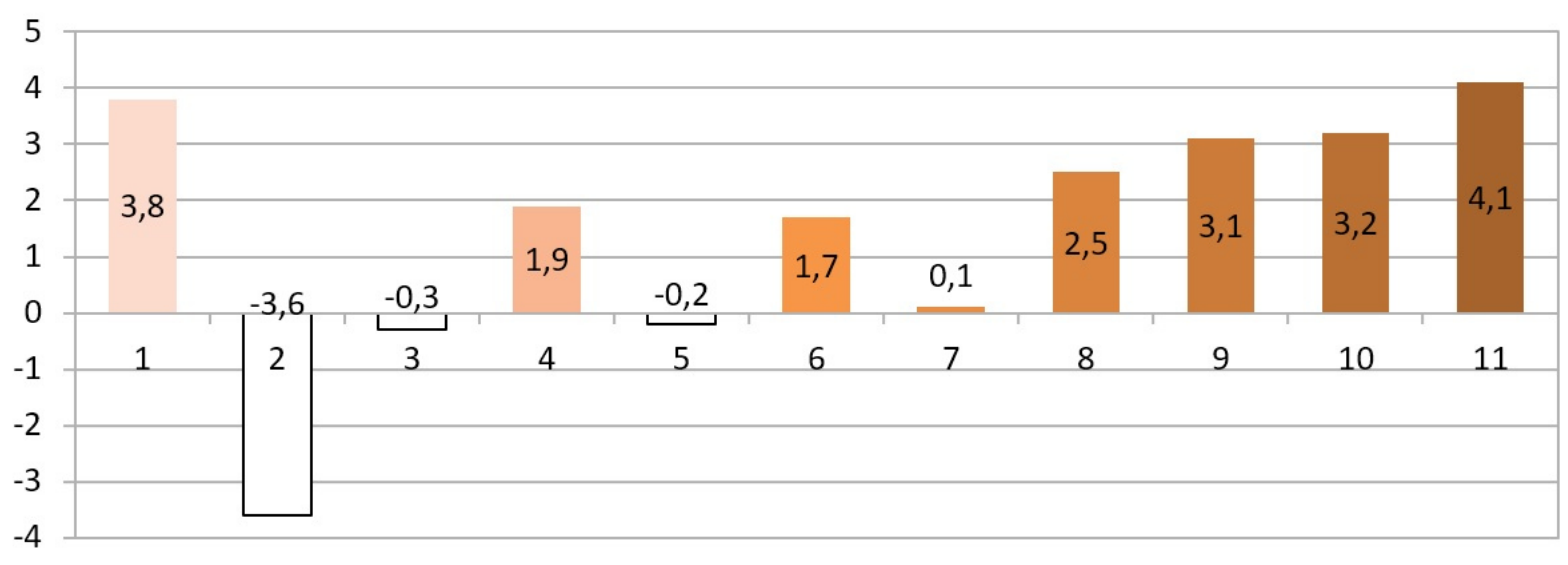

$\begin{array}{lllllllllll}2008 & 2009 & 2010 & 2011 & 2012 & 2013 & 2014 & 2015 & 2016 & 2017 & 2018\end{array}$

Grafikon 1. BDP - realni rast u \%

Izvor: Agencija za statistiku BiH

Ekonomski rast okruženja u prvom polugodištu je bio intenzivniji u odnosu na prvo polugodište 2014. uz blago intenziviranje stope u drugom u odnosu na prvo tromjesečje. Uticaj fiskalne politike na ekonomski rast u 2015. godini je bio prilično skroman kako po pitanju finalne potrošnje i transfera, tako i po pitanju javnih investicija. Projekcije ekonomskog rasta i zaposlenosti $u$ okruženju za 2015. godinu su znatno povoljnije u odnosu na rast iz 2014. godine. Jačanje rasta bi trebalo biti nastavljeno i u 2016., mada nešto skromnijim stopama. Tako je projicirani ekonomski rast Evro zone od 1,5\% za 2015. godinu znatno iznad stope od $0,9 \%$ u 2014 . godini. Potom slijedi nešto skromnije poboljšanje na stopu od $1,9 \%$ u 2016. godini. Ovo istina nije praćeno značajnijim poboljšanjem projekcija stope nezaposlenosti koja se tek neznatno popravlja u odnosu na 2014., te ostaje i dalje visoka $(10,5 \%)$ u 2016. godini.

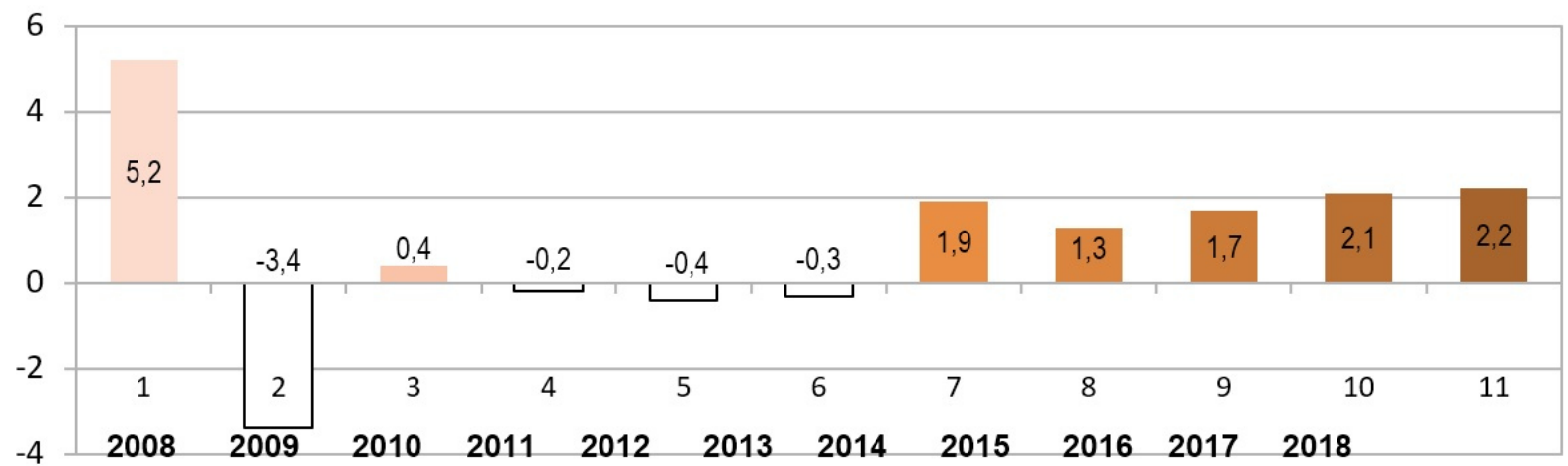

Grafikon 2. Finalna potrošnja - rast u \%

Među značajnijim zemljama iz okruženja, najznačajniji napredak se očekuje u Italiji i Hrvatskoj čiji pad od 0,4\% u 2014. je zaustavljen 2015. godine. Tada se očekuju pozitivne stope od $0,6 \%$ u Italiji, te $0,3 \%$ u Hrvatskoj, a snažan napredak ovih zemalja bi trebao biti nastavljen i u 2016. godini. S druge strane, u Sloveniji bi moglo doći do postepenog usporavanja ekonomskog rasta tokom 2015-2016. godine. Pored vanjskih pretpostavki, pretpostavke bh projekcija ne uključuju ponavljanje vremenskih nepogoda $u$

\section{Izvor: Agencija za statistiku BiH}

narednom periodu koje bi mogle (privremeno ili trajno) onesposobiti postojeće proizvodne kapacitete, te bitno uticati na poljoprivredu, proizvodnju električne energije i sl. Bruto nacionalni proizvod i njegovo formiranje iz domaćih izvora (investicije, razvoj), kao i iz inostranih izvora, je osnovni makroekonomski agregat (Ristić, Klincov, Komazec, \& Ristić, 2015).

S tim u vezi, očekivao se ekonomski rast od $2,5 \%$ 2015. godine nakon čega bi slijedilo dalje ubrzanje u 2016. sa realnom stopom od 3,1\%. Pretpostavlja 
se uobičajeno političko okruženje bez značajnijih kriza koje bi mogle dovesti u pitanje usvajanje budžeta i javne rashode. Sve ovo bi trebalo rezultirati bh ekonomskim rastom od 2,5\% u
2015., te $3,1 \%$ 2016. godine. Ovaj rast bi prije svega trebao biti nošen domaćom tražnjom, te u manjoj mjeri znatno sporijim rastom vanjskotrgovinskog deficita.

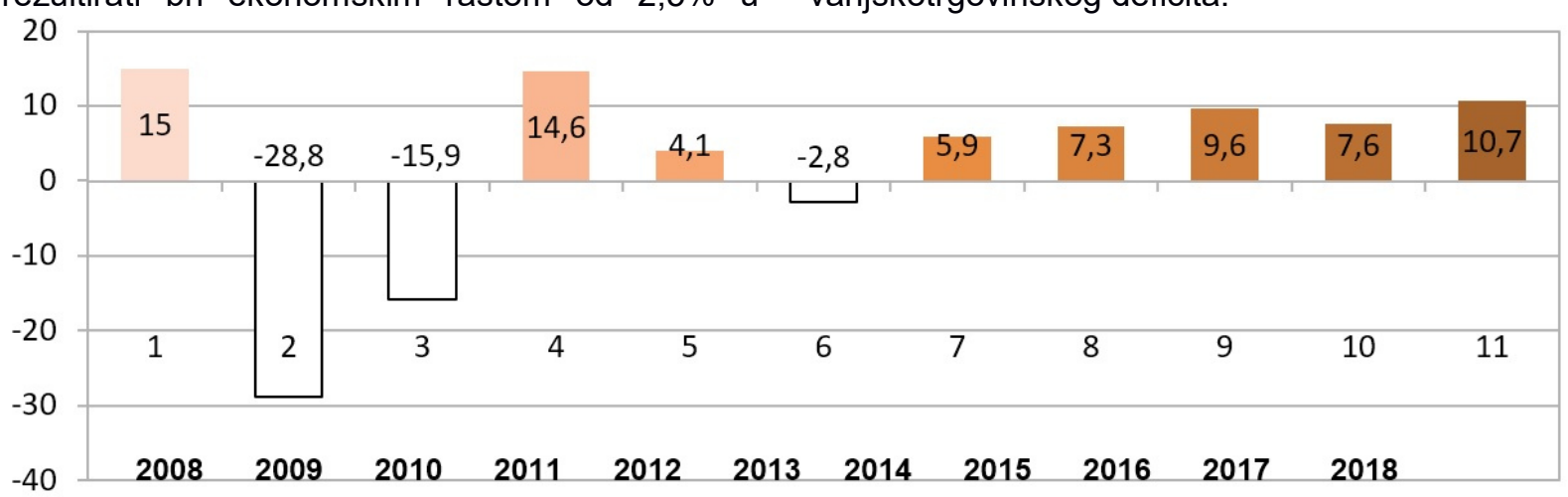

Grafikon 3. Investicije - rast u \%

Izvor: Agencija za statistiku BiH

Bolje vanjsko okruženje bi trebalo dovesti do jačanja izvozne tražnje i izvoza, ali i poboljšanja inostranih novčanih priliva kojima se finansira domaća tražnja. Ovo bi trebalo dovesti do realnog rasta finalne potrošnje od 1,3\% u 2015., odnosno $1,7 \%$ 2016. godine. Pored toga očekuje se značajan rast investicija u 2015. od $7,3 \%$, uz dalje poboljšanje stope od $9,6 \%$ u 2016. godini. Tako je ukupan rast domaće tražnje iznosio 2,3\% u 2015., odnosno $2,9 \%$ 2016. godine.

$S$ druge strane, rast izvoza bi trebao biti viši u odnosu na uvoz čime bi se negativan uticaj vanjskotrgovinskog deficita sveo na minimum tokom 2016. godine. Slične pretpostavke se očekuju i za period 2017.-18. uz nešto skromnije poboljšanje vanjskih pretpostavki u odnosu na prethodni period. S tim u vezi očekuje se ekonomski rast u $\mathrm{BiH}$ od $3,2 \%$ u 2017 ., te $4,1 \%$ 2018. godine. Slično kao i ranije, ovaj rast bi trebao biti nošen domaćom tražnjom uz skroman negativan doprinos vanjskog sektora. To podrazumjeva postepeno jačanje finalne potrošnje i investicija praćeno blagim rastom vanjskotrgovinskog deficita.

\subsection{Rast izvoza u Bosni i Hercegovini}

Preliminarni podaci ukazuju na stabilan trend rasta kada je u pitanju vanjskotrgovinska razmjena Bosne i Hercegovine sa svijetom. U periodu januar-juli 2015. godine vanjskotrgovinsku razmjenu u BiH karakterisali su povećanje ukupne robne razmjene, izvoza i u manjoj mjeri uvoza, smanjenje deficita i bolja pokrivenost uvoza izvozom u odnosu na isti period 2014. godine.
Ovaj pozitivni trend nastavljen je zahvaljujući jačanju izvozne tražnje u glavnim bh. trgovinskim partnerima, što potvrđuje niz kratkoročnih indikatora kao što desezonirani rast BDP-a u prva dva kvartala od oko $0,5 \%$, povećanje proizvodnje u prerađivačkoj industriji zemalja EU od 1,6\%, te višemesečni rast indeksa kompozitnog indeksa ekonomskih očekivanja ESI-(Economic Sentiment Indicator) koji je u julu 2015. godine dostigao vrijednost od 106,6. Poboljšanje izvozne tražnje za posljedicu je imalo povećanje ekonomske aktivnosti u $\mathrm{BiH}$, a posebno se to odnosi na rast proizvodnje $u$ bh. prerađivačkoj industriji od $3,3 \%$, što je predstavljalo ključnu determinantu kretanja bh. vanjskotrgovinske razmjene.

Tokom 2016. godine očekuje se nominalni rast ukupnog bh. izvoza od $5,6 \%$ u odnosu na prethodnu godinu, pri čemu je očekivani nominalni rast izvoza roba od $6 \%$, a izvoz usluga $4,4 \%$. S druge strane, imajući u vidu strukturu bh. ekonomije i izraženu visoku sklonost uvozu, povećanje finalne potrošnje i viši nivo poslovne aktivnosti realno je očekivati i povećanje bh. uvoza. Tako se tokom 2016. godine očekuje nominalno povećanje ukupnog bh. uvoza od $3,9 \%$, pri čemu bi očekivani uvoz roba porastao za $4 \%$, a uvoz usluga za $1,8 \%$. Ovo bi rezultiralo umjerenim povećanjem vanjskotrgovinskog deficita od $1,3 \%$.

Za period 2017.-2018. godine predviđa se potpuna normalizacija ekonomskih prilika i nešto sigurniji ekonomski rast, praćen rastom kako domaće tako i inostrane tražnje za robama. Navedeni rast bi trebao rezultirati povećanjem vanjskotrgovinske razmjene, te nešto višim 
stopama rasta izvoza roba u odnosu na uvoz. Nosilac bh. izvoza u ovom periodu trebala bi biti prerađivačka industrija u okviru koje bi uz tradicionalne izvozne grane dodatni doprinos trebale biti i ostale djelatnosti koje mogu realizovati svoj izvozni potencijal. Osim toga reformski procesi i unaprjeđenje kako poslovnog okruženja, standardizacije, te veća diversifikacija izvoznih tržišta trebala bi u značajnoj mjeri osnažiti bh-izvoz. Imajući u vidu i značaj sektora za proizvodnju električne energije u strukturi bh. izvoza očekuje se kontinuirani pozitivan doprinos i sa strane ovog sektora.

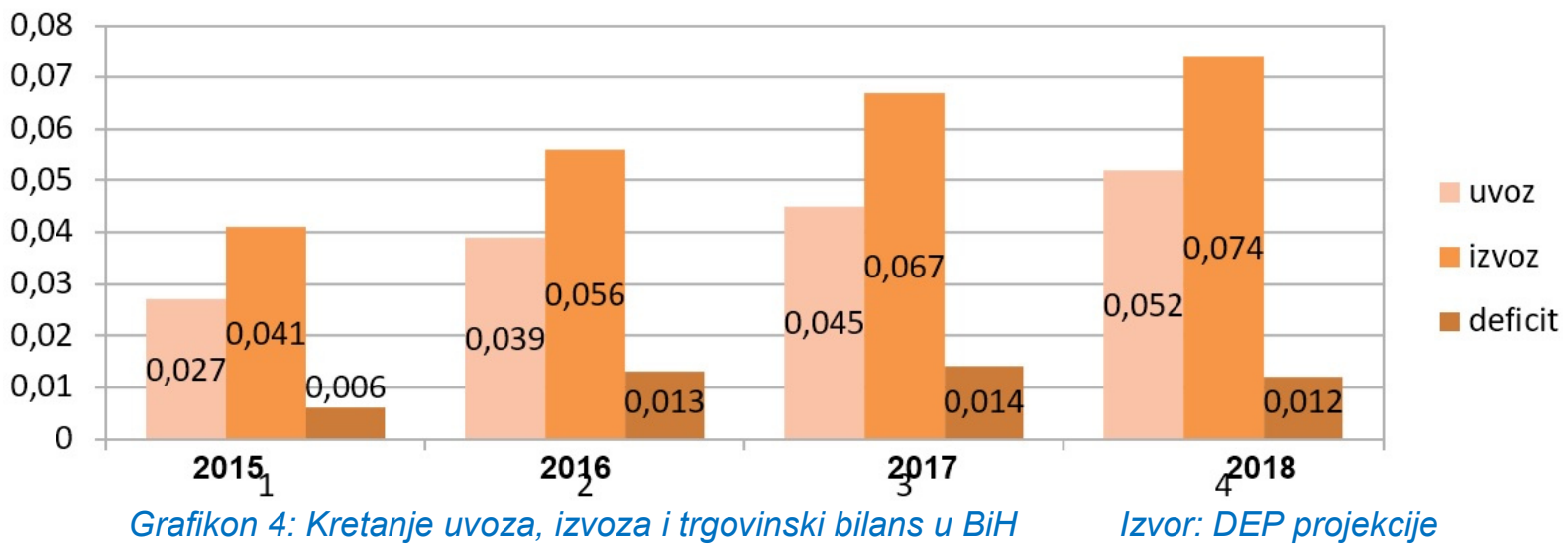

Posmatrano po zemljama najznačajniji dio bh. izvoza $72 \%$ plasiran je na tržište zemalja EU, a u 2015. godini povećan je za $1,6 \%$ u odnosu na prethodnu godinu. $U$ okviru EU najznačajnija izvozna tržišta su Njemačka (1,3 milijarde $\mathrm{KM})$, Italija (1,2 milijarde KM), Hrvatska (955 miliona KM), Austrija (755 miliona KM) i Slovenija (697 miliona KM). Najznačajnija povećanja izvoza registrovana su u Italiju 19,4\% i Austriju 10\%, dok je izvoz u Njemačku stagnirao 0,5\%. Izvoz u Hrvatsku je značajno smanjen za oko $20 \%$ uslijed promjene vanjskotrgovinskog režima prilikom ulaska Hrvatske u EU. Zemlje CEFTA-e čine 16\% bh izvoza, a tokom 2015. godine izvoz na ova tržišta povećan je za $1,7 \%$ u odnosu na prethodnu godinu. Najznačajniji udeo odnosi se na Srbiju u vrijednosti od 800 miliona KM i u 2015. godini povećan je za $4,5 \%$, dok je izvoz na tržište Crne Gore iznosio 293 miliona KM i povećan je za 8,5\% u odnosu na 2014. godinu.

Bh. uvoz iz zemalja EU povećan je za 4,8\%, a posmatrano po zemljama najviše stope rasta ostvarene su u okviru uvoza iz Italije $(11,6 \%)$ i Njemačke (7,8\%), dok je uvoz iz Hrvatske smanjen za 5,4\% u odnosu na 2014. godinu. Uvoz iz zemalja CEFTE čini $11 \%$ ukupnog bh. uvoza, pri čemu se većinski dio odnosi na uvoz iz Srbije (1,63 milijarde KM) koji je povećan za $10 \%$ u odnosu na 2014. godinu. Što si tiče ostalog dijela bh. uvoza značajno mjesto u strukturi zauzimaju:
Rusija (1,3 milijarde KM), Kina (1,35 milijardi KM) i Turska (580 miliona KM). Tokom 2014. godine s obzirom na pad cijena nafte u odnosu na 2013. godinu uvoz roba iz Rusije smanjen je za $15 \%$, dok je došlo do povećanja uvoza iz Kine od $48 \%$ i Turske od $18 \%$.

Prema raspoloživim projekcijama DGECFIN-a (proljetno izdanje) u zemljama EU očekuje se intenzivniji ekonomski oporavak sa očekivanom stopom rasta od $1,5 \%$. Osim toga, prema izvještaju DGECFIN-a nizak nivo cijena nafte, depresijaciju eura i kvantitativne olakšice Extended Asset Purchase Programme od strane ECB-a, te evropski investicijski plan - EU Investment Plan predstavljaće glavne mehanizme za povećanje ekonomske aktivnosti i intenzivnije vanjskotrgovinske razmjene kako unutar EU tako i sa trećim zemljama. Sve ove mjere u eksternom okruženju, uz očekivani ekonomski rast, viši nivo investicija i povećanje industrijske proizvodnje trebali bi rezultirati povećanjem vanjskotrgovinske razmjene u Bosni i Hercegovini. lako projekcije svjetskih cijena od strane međunarodnih institucija ne idu u korist bh. izvoznika, ipak se očekuje da bi povećanje proizvodnje tradicionalno izvozno orjentisanih grana bh. prerađivačke industrije uz značajan doprinos sektora za proizvodnju električne energije mogao rezultirati značajnim rastom bh. izvoza. 


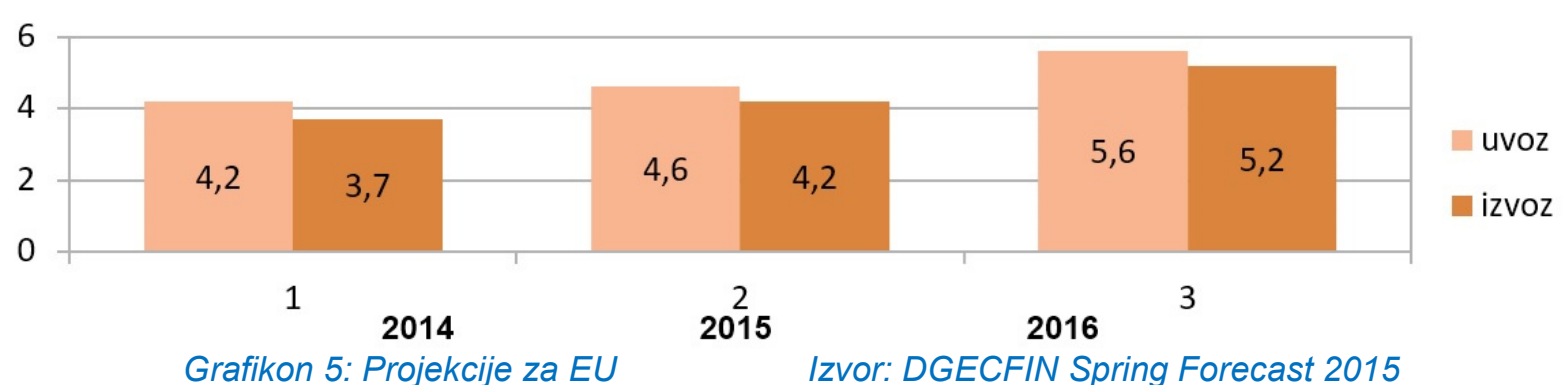

\subsection{Industrijska proizvodnja u Bosni i Hercegovini}

U prethodnih nekoliko godina glavnu determinantu kretanja industrijske proizvodnje u Bosni i Hercegovini predstavljalo je međunarodno ekonomsko okruženje, odnosno kretanje izvozne tražnje u glavnim trgovinskim partnerima. Ovo se ponajviše odnosi na prerađivačku industriju koja je u velikoj mjeri izvozno orjentisana, dok su kretanja u sektorima proizvodnja električne energije i rudarstvu određena internim dinamikama u $\mathrm{BiH}$.

Tabela 1: Indeksi industrijske proizvodnje u BiH za period 2010. - 2013. godine

\begin{tabular}{c|c|c|c|c|c|}
\hline \multicolumn{2}{|c|}{ Indeksi g/g } & $\mathbf{2 0 1 0}$ & $\mathbf{2 0 1 1}$ & $\mathbf{2 0 1 2}$ & $\mathbf{2 0 1 3}$ \\
\hline $\begin{array}{c}\text { Industrijska proizvodnja } \\
\text { fizički obim }\end{array}$ & $\mathrm{FBiH}$ & 104,2 & 102,5 & 95,7 & 107,3 \\
\hline & $\mathrm{RS}$ & 105 & 104,7 & 95,8 & 104,1 \\
\hline & $\mathrm{BiH}$ & 101,6 & 105,6 & 94,8 & 106,7 \\
\hline
\end{tabular}

Izvor: Direkcija za ekonomsko planiranje BiH

Industrijska proizvodnja u BiH tokom 2010. godine zabilježila je povećanje fizičkog obima proizvodnje od 1,6\%. Posmatrano po entitetima rast industrijske proizvodnje bio je dosta izraženiji i iznosio je 4,2\% u FBiH, odnosno 5\% u RS-u u odnosu na 2009. godinu. Tako je $\mathrm{BiH}$ industrijska proizvodnja u decembru 2010. povećana za 8,7\% u odnosu na decembar 2009. godine. Rast industrijske proizvodnje u decembru 2010. godine u FBiH iznosio $12,7 \%$, dok je stopa rasta u RS-u iznosila $14,1 \%$ u odnosu na isti mjesec 2009. godine.

U decembru 2011. godine evidentna je stagnacija (rast od 0,4\%) fizičkog obima industrijske proizvodnje $\mathrm{BiH}$ u odnosu na isti mjesec 2010. godine. Tokom decembra 2011. došlo je do poboljšanja proizvodnje u prerađivačkoj industriji i u sektoru rudarstva od $6,5 \%$ odnosno $5 \%$, dok je sektor proizvodnje električne energije zabilježio pad proizvodnje oko $16 \%$ u odnosu na decembar 2010. godine, što je glavni razlog stagnacije ukupnog indeksa industrijske proizvodnje u $\mathrm{BiH}$.

Međutim, ako se posmatraju rezultati na godišnjem nivou može se konstatovati da je došlo do djelimičnog oporavka $\mathrm{BiH}$ industrijske proizvodnje u 2011. godini u odnosu na prethodne godine. Rast izvozne tražnje u prvoj polovini 2011. godine rezultirao je povećanjem proizvodnje $u$ izvozno orjentisanoj prerađivačkoj industriji od 5\% i porastu proizvodnje u sektoru rudarstava od preko $15 \%$ na godišnjem nivou, dok rast proizvodnje u sektoru proizvodnje električne energije uslijed nepovoljne hidrološke situacije nije bio na nivou iz prethodnih godina i iznosio je svega $2 \%$ u odnosu na 2010 . godinu. Tako je $\mathrm{BiH}$ tokom 2011. godine ostvarila godišnji rast fizičkog obima industrijske proizvodnje od 5,6\% u odnosu na 2010. godinu.

Zatim je tokom 2012. godine u $\mathrm{BiH}$ registrovan pad fizičkog obima industrijske proizvodnje od 5,2\% u odnosu na 2011. godinu. Glavni razlog smanjenja industrijske proizvodnje bilo je slabljenje inostrane tražnje što je rezultiralo godišnjim padom proizvodnje u izvozno orijentisanoj prerađivačkoj industriji od 4,7\%. Posmatrajući performanse industrijske proizvodnje tokom 2012. godine može se konstatovati da su negativna ekonomska dešavanja u užem i širem okruženju, te izrazito nepovoljne vremenske prilike tokom prvog kvartala odredile ukupni rezultat $\mathrm{BiH}$ industrijske proizvodnje na kraju 2012. godine.

U 2013. godini kalendarski prilagođen rast fizičkog obima industrijske proizvodnje u $\mathrm{BiH}$ iznosio je $6,7 \%$ u odnosu na 2012. godinu. Međutim, 
potrebno je istaći da je ovaj rast ostvaren ponajviše zahvaljujući izrazito niskoj osnovici iz 2012. godine, te povoljnim vremenskim prilikama i blagom poboljšanju izvoza tokom 2013. godine. Ova relativno visoka stopa rasta djeluje prilično iznenađujuće ako se ima na umu da na nivou $\mathrm{BiH}$ nije došlo do povećanja broja zaposlenih, te da je većina glavnih trgovinskih partnera (izuzev Srbije) u 2013. godini zabilježila pad industrijske proizvodnje.
U 2014. godini BiH je zabilježila stagnaciju fizičkog obima industrijske proizvodnje. Nakon ohrabrujućeg rasta industrijske proizvodnje koji je u prvom kvartalu 2014. godine iznosio 4,5\%, već tokom drugog kvartala uslijed majskih poplava došlo je do naglog pada proizvodnje koja se uprkos određenim pozitivnim pomacima u drugom polugodištu nije uspjela značajnije oporaviti do kraja 2014. godine. Posmatrano po sektorima pozitivan doprinos industrijskoj proizvodnji ostvaren je samo $u$ domenu prerađivačke industrije od $3,8 \%$.

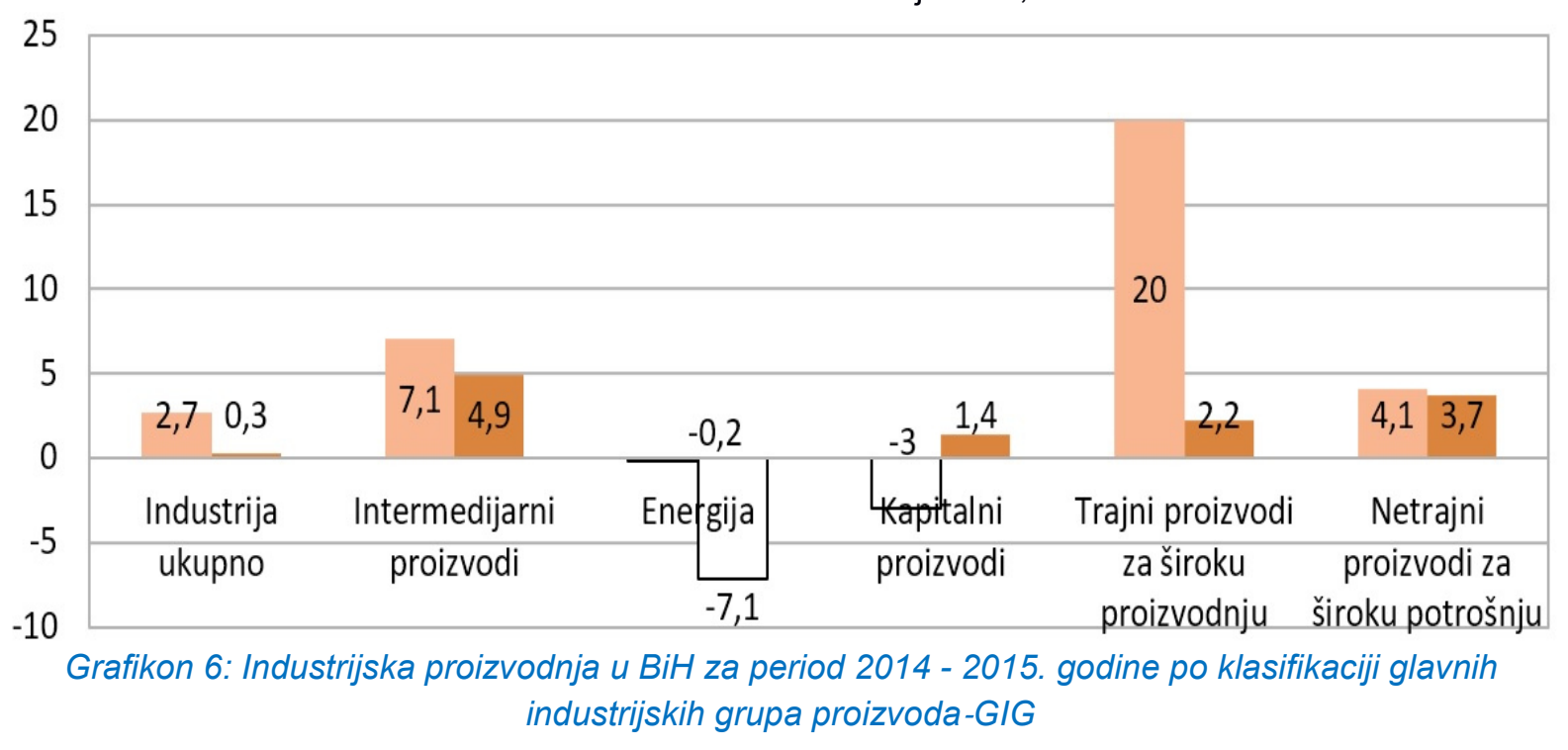

Izvor: Direkcija za ekonomsko planiranje BiH

U 2015. godini u BiH je nastavljen trend jačanja ekonomske aktivnosti. Tako je zahvaljujući pozitivnim dešavanjima u međunarodnom ekonomskom okruženju u 2015. godini u $\mathrm{BiH}$ registrovan rast industrijske proizvodnje od 2,7\% u odnosu na 2014. godinu. Ako se bh. industrijska proizvodnja u 2015. godini posmatra po sektorima evidentno je da je glavni generator rasta bila prerađivačka industrija koja je ostvarila povećanje proizvodnje od $4,8 \%$.

Obzirom da se potpuni oporavak većine industrija u EU očekuje u periodu 2017-2018. godine, izvjesno je očekivati da će ova dešavanja omogućiti i potpuni oporavak industrijske proizvodnje u $\mathrm{BiH}$. U ovom periodu očekuje se potpuna konsolidacija EU tržišta, oporavak privatne potrošnje, prevazilaženje problema oko finansiranja preduzeća i intenziviranje vanjskotrgovinske razmjene između zemalja EU. Pozitivan doprinos industrijskoj proizvodnji u EU treba očekivati i od mjera koje se tiču jačanja industrijske baze i konkurentnosti u zemljama EU. Ova pozitivna dešavanja u neposrednom okruženju trebala bi rezultirati povećanjem iskorišćenosti industrijskih kapaciteta u $\mathrm{BiH}$ koje se ogleda kroz povećani obim proizvodnje, viši nivo investicija kako kroz strana, tako i domaća ulaganja, što bi trebalo rezultirati osjetnijim povećanjem zaposlenosti u $\mathrm{BiH}$. Planirana investiciona ulaganja u infrastrukturu i energetiku, takođe bi trebala značajno doprinijeti jačanju kako građevinskog sektora u $\mathrm{BiH}$ tako i onih grana prerađivačke industrije koje su usko vezane uz građevinarstvo.

Takođe, se očekuje da energetski sektor koji je u prethodnom periodu bio jedan od nosilaca industrijske proizvodnje nastavi pozitivan trend rasta proizvodnje i dodatno osnaži industrijsku proizvodnju u $\mathrm{BiH}$ u navedenom periodu. Sve ovo bi trebalo rezultirati godišnjim povećanjem bh. industrijske proizvodnje od preko $5 \%$ u odnosu na prethodnu godinu. 


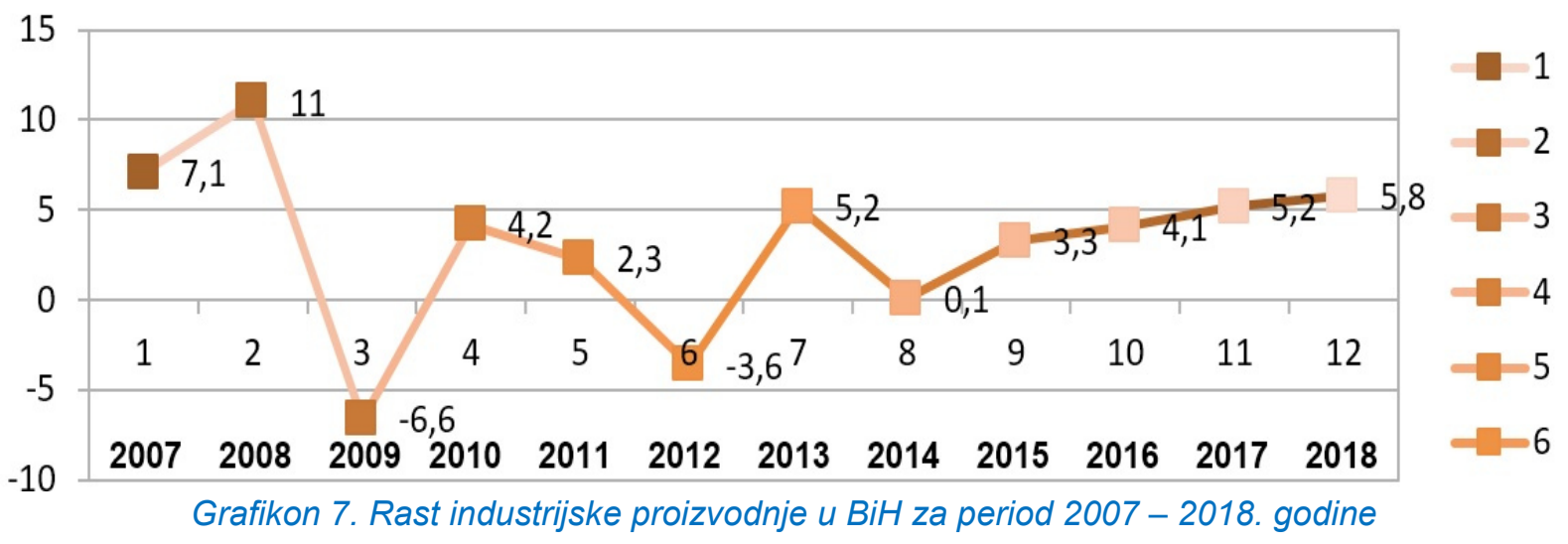

Izvor: Direkcija za ekonomsko planiranje BiH

lako je određeni napredak napravljen $u$ poslijeratnom periodu kada je prerađivačka industrija $\mathrm{BiH}$ rasla i stopama od $10 \%$, ovo je zaustavljeno u periodu tokom i nakon velike ekonomske krize u svijetu (uključujući i BiH) 2009. godine. Napredak, ali i još uvijek niska konkurentnost su možda najbolje ilustrovani tzv. „Indeksom industrijske konkurentnosti“ (CIP) koji objavljuje UNIDO prema kome $\mathrm{BiH}$ zauzima veoma nisku 83. poziciju (na listi od 133 zemlje) i to uprkos napretku od 13 mjesta u periodu 200012. Struktura CIP indeksa dosta jasno pokazuje zašto Bosna i Hercegovina ima slabiju konkurentsku poziciju u odnosu na konkurentske zemlje. Naime, BiH ima znatno niži nivo učešća prerađivačke industrije u BDP-a (10,2\% u 2014. godini) u poređenju sa zemljama Centralne i Istočne Evrope, a dodana vrijednost po glavi stanovnika u ovom sektoru je niža jedino u Srbiji. Pored toga, udeo srednje i visoko tehnoloških proizvoda u okviru prerađivačke industrije u $\mathrm{BiH}$ od $29,2 \%$ je prema posljednjem izvještaju dosta niži u odnosu Centralnu i Istočnu Evropu (CIE) čiji prosjek iznosi $44,5 \%$.

Investicije u nove kapacitete su prijeko potrebne da bi se povećala niska kapitalna opremljenost rada i podigla produktivnost, pa samim tim i konkurentnost bh. privrede. Pitanje konkurentnosti je izuzetno važno za BiH obzirom na veoma nizak životni standard i visok vanjskotrgovinski deficit. Nepovoljno poslovno okruženje u poređenju sa drugim zemljama je među glavnim razlozima nedovoljnog investiranja u $\mathrm{BiH}$. Isti uzroci vjerovatno odbijaju i strane investitore, pa otuda $i$ nizak nivo direktnih stranih ulaganja (SDU).
Pri tome su ocjene pojedinačnih parametara koji ulaze u zajedničku ocjenu "Doing Business“ "lakoća poslovanja“, u nivou zadnjeg do pretposljednjeg mjesta u poređenju sa izabranim zemljama. U nedostatku mogućnosti uticaja na neke spoljne faktore i događaje BiH bi trebala da obrati pažnju na ono što se može relativno jednostavno brzo promjeniti, kao što su eliminacija nepotrebnih administrativnih prepreka i smanjenje broja potrebnih dozvola za početak poslovanja i gradnje. Poseban naglasak treba dati na oblast "ekonomskog prava" koji se odnose na sprovođenje ugovora i zaštitu prava investitora (Blanchard, 2011).

Pored uobičajenih rizika za privlačenje stranog kapitala, treba posebno napomenuti i rizike po osnovu budućih stranih ulaganja u energetski sektor. Naime, značajan dio SDU do sada i u narednom periodu se odnosi na ulaganje $u$ velike projekte u oblasti rudarstva i dobijanje električne energije iz uglja (termoelektrane). Kao problem u budućnosti koji bi mogao smanjiti konkurentnost $\mathrm{BiH}$ u privlačenju SDU se pojavljuje ograničenje dozvoljene emisije $\mathrm{CO}_{2}$ u Evropskoj uniji. Ulaskom $\mathrm{BiH}$ u EU cijena koju bi BIH plaćala u vidu kazne (plaća se po toni emisije $\mathrm{CO}_{2}$ ) bi mogla znatno da poveća cijenu proizvodnje električne energije koja se proizvodi u termoelektranama. Time bi se svakako smanjila i konkurentnost u ovoj oblasti u privlačenju SDU i što će imati uticaja i na buduća domaća ulaganja u projekte dobijanja električne energije iz uglja.

Drugi značajan rizik za konkurentnost $u$ daljem privlačenju SDU predstavlja uvođenje sankcija prema $\mathrm{BiH}$ od strane Sekretarijata energetske 
zajednice koja okuplja zemlje evropske unije i zemlje Balkana zbog neusvajanja energetske strategije, ali i usvajanja Zakona o gasu na državnom nivou.

Sve ovo ukazuje da iako je Bosna i Hercegovina kao i ostale zemlje Zapadnog Balkana u procesu ekonomske tranzicije ostvarila određene pomake po pitanju ukupne makroekonomske stabilnosti, monetarne stabilnosti i inflacije, strukturalne reforme usmjerene ka podsticanju investicija radi jačanja konkurentnosti industrije i izvoza ostaju ključni izazovi kako bi uhvatile priključak u procesu ekonomske konvergencije sa zemljama EU28.

\section{KONKURENTSKA POZICIJA BOSNE I HERCEGOVINE}

Od 2005. godine, Svjetski Ekonomski Forum (WEF) svoju analizu konkurentnosti bazira na Globalnom Indeksu konkurentnosti (GCl), sveobuhvatnom okviru koji mjeri mikroekonomske i makroekonomske temelje nacionalne konkurentnosti koji se sastoji od 114 indikatora grupisanih u 12 stubova: Institucije, Infrastruktura, Makroekonomsko okruženje, Zdravstvo i osnovno obrazovanje, Visoko obrazovanje i stručna obuka, Efikasnost tržišta roba, Efikasnost tržišta rada, Razvoj finansijskog tržišta, Tehnološka spremnost, Veličina tržišta, Poslovna sofisticiranost i Inovacije. Svi stubovi su grupisani u tri grupe u skladu sa glavnim fazama razvoja: faza faktora (stubovi 1.- 4.), faza efikasnosti (stubovi 5.- 10.) i faza inovacija (stubovi 11. i 12.). lako svi stubovi koji su navedeni u izvjesnoj mjeri bitno utiču na ekonomiju zemlje, jasno je da drugačije utiču na različite zemlje. U skladu sa poznatim ekonomskim teorijama o fazama razvoja, Indeks konkurentnosti polazi od pretpostavke da sve zemlje prolaze kroz tri faze razvoja. U prvoj fazi ( faza faktora), za rast produktivnosti važni su osnovni faktori konkurentnosti: dobro funkcionisanje javnih i privatnih institucija (1. stub), dobro razvijena infrastruktura (2. stub), stabilan makroekonomski okvir (3. stub) i dobra, zdrava i pismena radna snaga koja ima najmanje osnovno obrazovanje (4. stub). Daljim razvojem, kako zemlje postaju konkurentnije, povećavaju produktivnost i ulaze u drugu fazu (faza efikasnosti) u kojoj ostvaruju efikasnije proizvodne procese i rastući kvalitet proizvoda. $U$ ovoj fazi na rast konkurentnosti utiču visoko obrazovanje i stručne obuke (5. stub), efikasno tržište roba (6. stub), efikasno funkcionisanje tržišta rada (7. stub), razvijenost finansijskog tržišta (8. stub), mogućnost iskorištavanja postojećih tehnologija (9. stub) i veličina tržišta (10. stub). Konačno, kako se dalje razvijaju, zemlje prelaze u treću fazu (faza inovacija) u kojoj je rast produktivnosti $i$ konkurentnosti uslovljen faktorima visoke poslovne sofisticiranosti (11. stub) i inovacijama (12. stub). Zbog toga dolazi i do značajnog povećanja plata, što utiče na visok životni standard građana zemalja koje se nalaze u trećoj fazi razvoja.

Postoje dva kriterijuma po kojem se zemlje svrstavaju u određenu fazu razvoja. Prvi je visina GDP-a po stanovniku u tržišnim cijenama. Drugi kriterijum se koristi za zemlje koje bi prešle u drugu fazu na osnovu učešća prihoda od izvoza mineralnih dobara u ukupnom izvozu roba $i$ usluga. Pretpostavlja se da su zemlje koje imaju više od $70 \%$ izvoza od mineralnih dobara u fazi koju pokreću osnovni faktori. Zemlje koje izvoze samo primarne proizvode, automatski su u početnoj fazi razvoja. Zemlje koje imaju bolje resurse i znatno su bogatije od zemalja koje su na granici tehnoloških dostignuća, svrstavaju se u treću fazu koju pokreću inovacije. Zemlja koja je između ove tri faze je u takozvanoj fazi tranzicije.

Konkurentnost se definiše kao skup institucija, politika i faktora koji određuju nivo produktivnosti jedne zemlje. Nivo produktivnosti, predstavlja nivo napretka koji neka ekonomija može dostići. Nivo produktivnosti, takođe određuje stope povrata investicija koje i jesu temeljni pokretači ekonomskog razvoja. Konkurentnija ekonomija je ona koja će brže rasti i razvijati se u budućnosti.

Pozicija $\mathrm{BiH} u$ relevantnim rangiranjima $i$ izvještajima o konkurentnosti, kao što su izvještaji Svjetskog ekonomskog foruma (WEF) ili Svjetske banke (WB), je loša - BiH se nalazi na začelju svih lista. Prema Izvještaju o globalnoj konkurentnosti WEF, BiH je među 140 rangiranih ekonomija je na 111. mjestu po opštoj konkurentnosti. BiH se nalazi iza Etiopije, koja je na 109. mjestu i Albanije na 93. mjestu. 
Tabela 2. GCl - Indeks globalne konkurentnosti BiH

\begin{tabular}{|c|c|c|}
\hline & Rang & Ocjena \\
\hline GCI 2015-2016 ( od 140 ze m alja) & 111 & 3,7 \\
\hline GCl 2014-2015 (od 144 zemlje) & $\mathrm{N} / \mathrm{a}$ & $\mathrm{N} / \mathrm{a}$ \\
\hline GCl 2013-2014 (od 148 zemalja) & 87 & 4 \\
\hline GCI 2012-2013 (od 144 zemlje) & 88 & 3,9 \\
\hline GCl 2011-2012 (od 142 zemlje) & 100 & 3,8 \\
\hline GCl 2010-2011 (od 139 zemalja) & 102 & 3,7 \\
\hline GCl 2009-2010 (od 133 zemlje) & 109 & 3,5 \\
\hline GCl 2008-2009 (od 134 zemlje) & 107 & 3,6 \\
\hline GCl 2007-2008 (od 131 zemlje) & 106 & 3,6 \\
\hline Osnovni us lovi $(40,0 \%)$ & 95 & 4,2 \\
\hline 1. stub: Institucije & 127 & 3,2 \\
\hline 2. stub: Infrastruktura & 103 & 3,1 \\
\hline 3. stub: Makroekonomsko okruženje & 98 & 4,3 \\
\hline 4. stub: Zdravstvo i osnovno obrazovanje & 48 & 6 \\
\hline Povećanje efikas nosti $(50,0 \%)$ & 112 & 3,5 \\
\hline 5. stub: Visoko obrazovanje i stručna obuka & 97 & 3,8 \\
\hline 6. stub: Efikasnost tržišta roba & 129 & 3,7 \\
\hline 7. stub: Efikasnost tržišta rada & 131 & 3,4 \\
\hline 8. stub: Razvoj finansijskog tržišta & 113 & 3,3 \\
\hline 9. stub: Tehnološka spremnost & 79 & 3,6 \\
\hline 10. stub: Veličina tržišta & 97 & 3,1 \\
\hline Inovacije i sofist. Faktora $(10,0 \%)$ & 120 & 3 \\
\hline 11. stub: Poslovna sofisticiranost & 125 & 3,3 \\
\hline 12. stub: Inovacije & 115 & 2,8 \\
\hline
\end{tabular}

Izvor: UNIDO - United Nations Industrial Development Organization.

Prema međunarodnim poređenjima Svjetske banke, $\mathrm{BiH}$ je rangirana kao 125 . od 183 poređene ekonomije. Svjetska banka rangira ekonomije prema stepenu prilagođavanja poslovnog okruženja ulagačima, i ispituje regulativu poslovnog poduhvata, dobijanje građevinskih dozvola, dobijanje priključaka za struju, registracije vlasništva, dobijanje kredita, stepena zaštite investitora, plaćanja poreza, olakšanosti vanjske trgovine, stepenu sprovođenja ugovora i solventnosti. Analiza pojedinačnih kriterija pokazuje da je $\mathrm{BiH}$ najgore rangirana po mogućnosti dobijanja građevinske dozvole (163. od 183 rangirane ekonomije) i pokretanju poslovnog poduhvata (162. od 183 rangirane ekonomije), a najbolji pojedinačni rang ima po mogućnosti dobijanja kredita (na 67. mjestu) i solventnosti (na 80. mjestu od 183 rangirane ekonomije). Loš rang $\mathrm{BiH}$ prouzrokovan je prije svega neefikasnošću vlasti u registraciji preduzeća, vlasništva i dobijanja potrebnih licenci, te stepena sprovođenja ugovora (efikasnost rada sudova).
$\mathrm{U}$ globalnom pregledu trgovinskih tokova, $\mathrm{BiH}$ je rangirana kao 80 . od 125 poređenih ekonomija, te je poboljšala svoj rang sa 102. mjesta u prethodnom pregledu. Međunarodna komparacija sprovođenja reformi koju sprovodi Organizacija za ekonomski razvoj i saradnju (OECD), pokazuje da $\mathrm{BiH}$ u posljednjih pet godina nije ostvarila pomake ni na jednom polju osim sprovođenja poreskih reformi i reforme procesa registracije preduzeća. OECD pregled reformi u oblasti ljudskog kapitala pokazuje da $\mathrm{BiH}$ u odnosu na posljednji pregled koji je napravljen 2006. godine nije ostvarila pomake u sprovođenju reformi u oblasti ljudskog kapitala. Napredak BiH u primjeni Evropske povelje o malim i srednjim preduzećima u zadnjem pregledu je takođe ocijenjen kao vrlo mali.

Sve međunarodne ocjene i pregledi pokazuju da je $\mathrm{BiH}$ u lošoj konkurentskoj poziciji. Ključni razlozi koji postavljaju BiH na takvo mjesto su neefikasnost javne vlasti i zastoj u sprovođenju reformi. Prema ocjeni investicione klime zemalja koju sprovodi Svjetska Banka, neefikasna javna vlast, neefikasan regulatorni režim, loša struktura 
ekonomije i neefikasno funkcionisanje tržišne ekonomije su osnovne karakteristike koje stvaraju lošu klimu za investitore u $\mathrm{BiH}$.
$\mathrm{Na}$ grafikonu 8 je prikazana struktura faktora koji najviše ometaju poslovanje $\mathrm{u} \mathrm{BiH}$ i na taj način najviše utiču na nizak nivo konkurentnosti bh ekonomije.

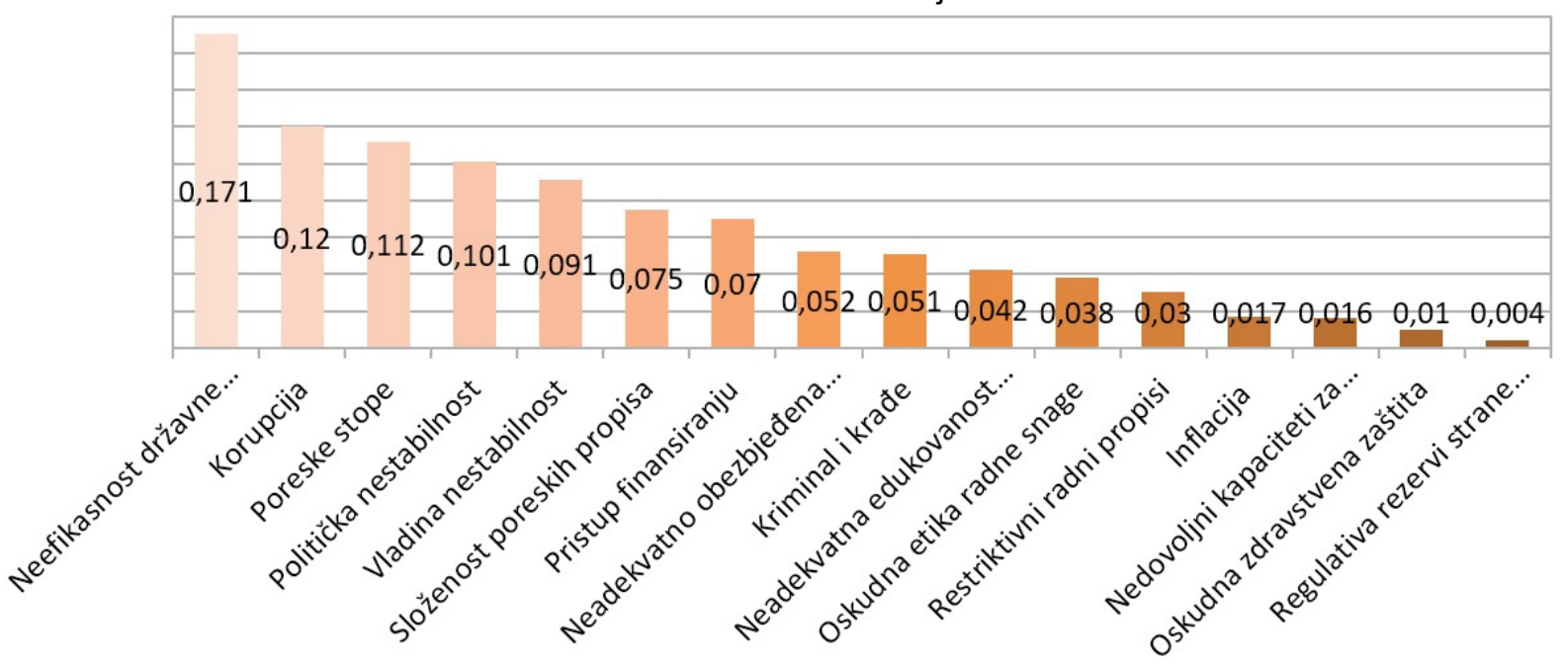

Grafikon 8. Faktori koji najviše ometaju poslovanje u BiH

Izvor: European Economic Forecast

Prema podacima Konferencije za trgovinu i razvoj Ujedinjenih nacija (UNCTAD), $\mathrm{BiH}$ je na posljednjem mjestu $u$ regionu po privlačenju direktnih stranih ulaganja (FDI), te je u 2010. privukla tri puta manje investicija od Makedonije, a 15 puta manje od Srbije.

Osim loše međunarodne konkurentnosti $\mathrm{BiH}$ po pitanju privlačenja stranih investitora, bh ekonomija i preduzeća iz $\mathrm{BiH}$ imaju značajna ograničenja po pitanju konkurentnosti na međunarodnim tržištima. Izvozne grane i proizvodi $\mathrm{BiH}$ zasnivaju se na proizvodima sa niskom dodanom vrijednosti (value added), te na inputima, kao što je npr. električna energija, koji su dijelom ili u potpunosti subvencionisani. Dok je u periodu prije 1991. izvoz BiH počivao u značajnoj mjeri na gotovim proizvodima ili proizvodima $u$ finalnoj bazi obrade, danas je ta slika obrnuta. Velika preduzeća iz $\mathrm{BiH}$, koja su nekad izvozila robe i usluge $u$ iznosima koji su ih činili globalnim konkurentima, danas dobijaju ugovore relativno malih vrijednosti najčešće preko posrednika, ili su angažovani kao podugovarači. Ona preduzeća koja su aktivni izvoznici sa velikim izvoznim potencijalom se suočavaju sa značajnim preprekama po pitanju sertifikovanja, standardizacije i prateće dokumentacije za izvozne poslove. Kao ilustracija može poslužiti činjenica da izvoznici bh. namještaja dostavljaju nalaze ispitivanja kvaliteta namještaja i materijala iz Hrvatske, jer u $\mathrm{BiH}$ ne postoji adekvatan institut.
Ovo značajno poskupljuje finalni proizvod. Slična situacija je i sa proizvodima animalnog porijekla, jer $\mathrm{BiH}$ nema međunarodno priznatu labaratoriju čiji su nalazi međunarodno prihvaćeni. Rješenja koja trenutno omogućavaju izvoz su ad hoc ili „vansistemskog“ tipa.

Značajno ograničenje konkurentske pozicije je prouzrokovano i nedostatkom kadrova odgovarajućih kvalifikacija, te nedostatkom pristupa novim tehnologijama. Ukoliko želi nastaviti tendenciju rasta izvoza i jačanje svoje konkurentske pozicije, BiH će morati adekvatno riješiti sva navedena pitanja. Jedno od mogućih rješenja tehnološkog jaza je i privlačenje direktnih stranih ulaganja, a nedostatak odgovarajućih kvalifikovanih profila se u kratkom roku može riješiti uvozom kadrova, dok se u srednjem i dugom roku može očekivati prilagođavanje obrazovnog sistema potrebama razvoja $\mathrm{BiH}$.

\section{RANG ZEMALJA U GLOBALNOJ KONKURENTNOSTI}

Kao i prethodnih godina, ovogodišnjim „Top 10“ još uvijek dominiraju napredne evropske zemlje i nekoliko Azijskih "tigrova“. Sedmu godinu zaredom Švicarska je na liderskom mjestu među prvih 10, a Singapur i ove godine zadržava zasluženo mjesto kao druga najkonkurentnija ekonomija na svijetu. Poredak prvih 10 zemalja se nije znatno promijenio u odnosu na prošlu godinu. 
Tabela 3. Rang zemalja u globalnoj konkurentnosti 2015 - 2016

\begin{tabular}{l|c|c|c|}
\hline Zemlja/Ekonomija & GCI 2015-2016 & & GCI 2014-2015 \\
RANG (od 140) & Ocjena & RANG (od 144) \\
\hline Switzerland & 1 & 5,76 & 1 \\
\hline Singapore & 2 & 5,68 & 2 \\
\hline United States & 3 & 5,61 & 3 \\
\hline Germany & 4 & 5,53 & 5 \\
\hline Netherlands & 5 & 5,5 & 8 \\
\hline Japan & 6 & 5,47 & 6 \\
\hline Hong Kong SAR & 7 & 5,46 & 7 \\
\hline Finland & 8 & 5,45 & 4 \\
\hline Sweden & 9 & 5,43 & 10 \\
\hline United Kingdom & 10 & 5,43 & 9 \\
\hline Bulgaria & 54 & 4,32 & 54 \\
\hline Slovenia & 59 & 4,28 & 70 \\
\hline Macedonia, FYR & 60 & 4,28 & 63 \\
\hline Montenegro & 70 & 4,2 & 67 \\
\hline Croatia & 77 & 4,07 & 77 \\
\hline Albania & 93 & 3,93 & 97 \\
\hline Serbia & 94 & 3,89 & 94 \\
\hline Bosnia and Herzegovina & 111 & 3,71 & $\mathrm{~N} / \mathrm{a}$ \\
\hline
\end{tabular}

Izvor: European Economic Forecast

$\mathrm{Na}$ međunarodnim finansijskim tržištima, a posebno na tzv. evro tržištu, prisutne su brojne inovacije, koje su od posebnog značaja za preduzeća i druge finansijske subjekte. Kad to konstatujemo, imamo u vidu potrebu poboljšanja izvora finansiranja, identifikovanja načina obezbjeđenja od rizika finansiranja, ofanzivnog uticaja na prosječnu tržišnu cijenu kapitala i maksimiziranja ukupne dobiti (Ristić, Komazec, \& Ristić, 2015/2016).

Švicarska je na vrhu rang liste i zadržala je prvo mjesto i ove godine sa najboljom ocjenom. Ona vodi u stubu inovacija, visokom potrošnjom na istraživanja i razvoj i dobrom saradnjom akademske zajednice i privatnog sektora. Takođe i ostali faktori doprinose inovacijskom ambijentu uključujući nivo poslovne sofisticiranosti i kapaciteta zemlje da zadrži i privuče nove talente. Švicarska se može pohvaliti odličnim obrazovnim sistemom i pionir je u dualnom sistemu obrazovanja. Tržište rada je veoma djelotvorno s visokim nivoom saradnje između poslodavca i radne snage uz balans zaštite zaposlenika i zahtjeva poslodavaca. Švicarske javne institucije su najtransparentnije i najefikasnije kao i njeno makroekonomsko okruženje koje je među najstabilnijim u svijetu.
Singapur i dalje zauzima drugo mjesto, već pet godina zaredom, kao jedna od najdosljednijih zemalja u svojim performansama sa visokim ocjenama u 10 od 12 stubova. I dalje ostaje vodeća zemlja kada je u pitanju efikasnost tržišta i jedna od dvije najbolje zemlje zajedno sa Hong Kongom $u$ efikasnosti tržišta roba, rada i finansijskom tržištu. Singapur se može osloniti na fleksibilno i drugo najkonkurentnije tržište rada u svijetu, iako je sudjelovanje žena u radnoj snazi i dalje relativno nisko. Sa najboljim sistemom visokog obrazovanja, u dobroj je poziciji da poveća usvajanja novih tehnoloških rješenja, poslovnu sofisticiranost i inovacije, i ima stabilno makroekonomsko okruženje i transparentan i djelotvoran institucionalni okvir.

Sjedinjene Američke Države su zadržale 3. mjesto na ljestvici najkonkurentnijih zemalja iako se naziru mnogi rizici u ekonomiji. Oporavak i rast privrede se može graditi na poboljšanjima $u$ institucijama, performansama javnog sektora i makroekonomskom okruženju koji su ocjenjeni sa višim ocjenama nego prethodnih godina. Najveća snaga SAD-a je jedinstvena kombinacija izuzetnih inovacija, velikog tržišta i poslovne sofisticiranosti. Kapacitet inovacija povećavaju saradnja univerziteta i preduzeća, visoko stručni ljudski kapital i značajna potrošnja na istraživanje i razvoj. 
lako se monetarna politika lagano normalizuje i američki dolar jača, zemlja će se ipak morati okrenuti nizu reformi kako bi osigurala dalji rast produktivnosti i konkurentnosti.

Njemačka se ove godine popela za jedno mjesto na 4. poziciju boljim pokazateljima vezanim za radnu snagu, makroekonomsko okruženje i efikasno finansijsko tržište, što se odrazilo na pozitivan budžetski račun i smanjenje državnog duga koji čini $73 \%$ BDP-a. Posebno se ističe $u$ složenijim područjima konkurentnosti sofisticiranosti, inovacijama, te implementaciji novih tehnologija u poslovnim procesima. Visokoj ocjeni konkurentnosti doprinosi visoka potrošnja na istraživanje i razvoj i okoliš, kao i dobra poslovna saradnja univerziteta i institucija čime se osigurava usklađenost vještina sa poslovnim potrebama.

Holandija je na 5 . mjestu ove godine, čime se popela na najvišu poziciju ikada. Postigla je veliki napredak u obrazovanju, infrastrukturi i stubu institucija. I dalje ostaje jedna od najsofisticiranijih i najinovativnijih zemalja u svijetu sa otvorenim i djelotvornim tržištem roba. lako poboljšano, tržište rada, još uvijek ne prati ostale stubove konkurentnosti, posebno kada je riječ o fleksibilnosti određivanja plata. lako se makroekonomsko okruženje poboljšava, Holandija još uvijek radi na oporavku od „pucanja balona“ domaćih nekretnina prouzrokovanog globalnom finansijskom hipotekarnom krizom.

Japan ostaje na 6 . mjestu ostvarujući neznatne promjene $u$ polovini stubova posebno $u$ makroekonomskom okruženju, zahvaljujući povratku umjerene inflacije koja generiše povećanje poreza na potrošnju. Japan ima veliku korist od odlično opremljene infrastrukture i jedna je od najzdravijih zemalja kada je u pitanju radna snaga koja ima životni vijek starosti 80 godina. Ima dobre performanse u složenijim područjima konkurentnosti iako će u budućnosti od presudnog značaja biti jačanje ljudskog kapitala, udjela žena u radnoj snazi i korištenje talenata.

Hong Kong je na listi top 10 zemalja od 2012. godine i zadržava 7 . mjesto već tri godine zaredom sa skoro istim rezultatima u svih 12 stubova. I dalje vodi u stubu infrastrukture ispred Singapura održavajući izuzetan kvalitet svih sadržaja u svim vidovima transporta. lako je skliznuo sa vrha, finansijski sektor je i dalje jako dobro razvijen, sa visokim nivoom sofisticiranosti, pouzdanosti i stabilnosti i relativno dobrim pristupom kreditiranju. Kao i kod Singapura, razvijenost tržišta roba i veličina tržišta doprinosi odličnoj ukupnoj ocjeni, kao i činjenica da je zemlja jedna od najvećih implementatora tehnoloških inovacija.

Nordijske zemlje su ove godine nešto lošije rangirane. Finska je pala na 8 . mjesto, a pad koji je zabilježila ove godine prouzrokovan je šokovima vezanim za sankcije Rusiji i smanjenje svog najvećeg, ruskog izvoznog tržišta. Ipak njene institucije su transparentne i efikasne, visoko obrazovanje i sistem edukacije je među najboljima na svijetu, kao i poslovni sektor koji je jedan od najinovativnijih.

Švedska je ove godine pretekla Veliku Britaniju i zauzela 9. mjesto što je rezultat efikasnog i transparentnog institucionalnog okvira koji u paru sa obrazovnim sistemom čini zemlju jednu od najvećih svjetskih inovatora. Restriktivni propisi o radu su i dalje ispod nivoa najbolje ocijenjenih zemalja u ovoj oblasti. Visoka ukupna poreska stopa na dobit u Švedskoj, iako smanjena ispod $50 \%$, visoko je iznad međunarodnih standarda, što može uticati na investicije $u$ inače konkurentnom i otvorenom domaćem tržištu.

Velika Britanija je poboljšala svoje rezultate, ali ne dovoljno kako bi se nosila sa svojim konkurentima, te ove godine bilježi 10. mjesto. Stvorila je dobar set uslova za uslužni sektor i razvoj Londona kao epicentra Evropske tehnologije. Ima čvrste i jake institucije, jaku zaštitu prava vlasništva i efikasan pravosudni sistem. Zahvaljujući sposobnosti da privuče talente iz inostranstva kao i činjenici da ima najbolje univerzitete u svijetu, može računati na dobro obrazovanu radnu snagu koja doprinosi usvajanju novih tehnologija. lako se još uvijek oporavlja od globalne finansijske krize, finansijsko tržište Velike Britanije je i dalje jedno od najrazvijenijih u svijetu. U dugom roku zemlja će morati poboljšati makroekonomsko okruženje, smanjivati državni deficit i javni dug.

\section{ZAKLJUČAK}

Ekonomija BiH bilježi oporavak i visoke stope rasta, ali na relativno nisku osnovicu. Nezaposlenost u $\mathrm{BiH}$ je velika sa tendencijom povećanja usljed efekata svjetske ekonomske krize. Učešće javnog sektora u ekonomiji je 
visoko, a BiH se u posljednje dvije godine suočava sa deficitom. Izvoz roba iz $\mathrm{BiH}$ raste, što dovodi do smanjenja vanjskotrgovinskog deficita, ali je on još uvijek visok (oko $30 \%$ BDP, ili 52\% pokrivenosti uvoza izvozom). U strukturi izvoza iz $\mathrm{BiH}$ dominiraju bazni metali i njihovi proizvodi $(22.7 \%$ ukupnog izvoza), dijelovi za auto industriju (9.8\%), namještaj $(9.6 \%)$, hemijski proizvodi $(6.9 \%)$, te električna energija i mineralna goriva. Smanjenje trgovinskog deficita i rast BiH izvoza je jedna od temeljnih odrednica ekonomske i vanjske politike $\mathrm{BiH}$, te ovom pitanju vlade na svim nivoima daju nominalno visok rang prioriteta. Međutim, konkretne mjere na sprovođenju politika i aktivnosti nisu usklađene sa ovim strateškim ciljem, a ukupni budžeti izdvojeni za ovu svrhu ne pokazuju da je ovom cilju dodijeljen toliko visok rang prioriteta.

Neophodno je što prije ubrzati sprovođenje obaveza koje je $\mathrm{BiH}$ preuzela potpisivanjem Sporazuma o stabilizaciji i pridruživanju sa EU. Ova preporuka se prije svega odnosi na usvajanje novih i adaptaciju postojećih propisa koji se odnose na konkurentnost, te jačanje javne uprave. Ubrzanje procesa i ispunjavanje $\mathrm{BiH}$ obaveza će direktno poboljšati konkurentnost $\mathrm{BiH}$ kroz efikasniju javnu upravu i sudstvo, propise koji regulišu slobodan protok ljudi, roba i kapitala, štite domaće i strane investitore i omogućavaju funkcionisanje tržišta.

$\mathrm{U}$ oblasti jačanja konkurentnosti $\mathrm{BiH}$ koje su u nadležnosti javnih i regulatornih institucija postoje jasne smjernice (kao što su npr. Potrebne laboratorije, zakonski propisi i standardi), koje su identifikovane $u$ međunarodnim analizama $i$ poređenjima. Osim djelovanja u regulatornom okruženju, BiH mora ojačati i privatni sektor kroz direktnu državnu intervenciju. Izvozno konkurentna preduzeća je potrebno ojačati podsticajima, poreskim olakšicama i finansijskom podrškom izvoznim poslovima (garancijama $\mathrm{i}$ kreditiranjem izvoznih poslova). Ovo naravno u BiH nije moguće zbog CEFTA i drugih trgovinskih sporazuma, ali je moguće podržati razvoj izvoznih preduzeća na način kako to čine zemlje $u$ okruženju (finansiranje izvoznih poslova kroz razvojne banke i fondove, poreske olakšice i sl.).

Transfer novih tehnologija jedna je od glavnih konkurentskih prilika za $\mathrm{BiH}$. Zbog ograničenih sredstava koje $\mathrm{BiH}$ ima na raspolaganju za istraživanje i razvoj novih tehnologija, najbrži razvojni put je transfer novih tehnologija kroz privlačenje direktnih stranih ulaganja. $\mathrm{BiH}$ je do sada ostvarila vrlo skromne rezultate po pitanju privlačenja stranih investicija, pa je na ovom polju potrebno napraviti velike iskorake. „Mapa puta“ je navedena u svim značajnijim međunarodnim izvještajima, kao i u analizama atraktivnosti $\mathrm{BiH}$ za ulaganje i pokretanje poslovnog poduhvata. $\mathrm{BiH}$ mora stvoriti okruženje koje je maksimalno atraktivno za strane investitore, te usmjeriti sve raspoložive resurse u stvaranje povoljnog ambijenta za razvoj poslovnog sektora u $\mathrm{BiH}$.

Tehnološki jaz i nedostatak obrazovnih profila i specijalističkih znanja, koji mogu uticati na konkurentnost, potrebno je otkloniti intervencijama u obrazovnom sistema. Preporučuje se nastavak i ubrzanje reformi obrazovnog sistema koje vode ka ispunjenju ovog cilja, te uspostava i finansiranje fonda za istraživanje i razvoj i fonda za stipendiranje deficitarnih obrazovnih profila $i$ specijalizanata. Ova dva fonda bi trebala biti osnovana (i finansirana) u saradnji javnog i privatnog sektora, te bi trebala direktno adresirati potrebe preduzeća iz privatnog sektora sa najvećim izvoznim i konkurentskim potencijalom.

\section{CITIRANI RADOVI}

Agencija za statistiku BiH. (2016). Indeks obima industrijske proizvodnje u BiH za 2015. godinu. [Zvanični podaci]. Dostupno na veb sajtu Agencije za statistiku BiH: http://www.bhas.ba/index.phpoption=com_publikacija\&view=publikacija_pregled\&ids=3\&id=3\& $\mathrm{n}=$ Industrija

Blanchard, O. (2011). Makroekonomija (peto izdanje). Zagreb: MATE.

Direkcija za ekonomsko planiranje BiH. (2016). Informacije o kretanju makroekonomskih pokazatelja u $\mathrm{BiH}$. [Zvanični podaci]. Dostupno na veb sajtu Direkcije za ekonomsko planiranje BiH: http://www.dep.gov.ba/Default.aspx?langTag=bs-BA\&template_id=139\&pagelndex=1 
European Economic Forecast. (2016). The movement of World oil prices, food and inflation. [Data file]. Dostupno na veb sajtu European Economic Forecast: http://ec.europa.eu/economy_finance/publications/index_en.htm

Ristić, K. (2015/2016). Međunarodne monetarne i javne institucije (drugo izdanje). Beograd: EtnoStil.

Ristić, K., Klincov, R., Komazec, S., \& Ristić, Ž. (2015). Napredna ekonomija. Beograd: EtnoStil.

Ristić, K., Komazec, S., \& Ristić, Ž. (2015/2016). Globalni finansijski menadžment (treće izdanje). Beograd: EtnoStil.

United Nations Industrial Development Organization. (2016). Competitive Industrial Performance Index. Dostupno na veb uNIDO: http://www.unido.org/search.html?tx_indexedsearch_pi2\%5Baction\%5D=search\&tx_indexeds earch_pi2\%5Bcontroller\%5D=Search

Datum prve prijave:

Datum prijema korigovanog članka:

Datum prihvatanja članka:
24.03.2016.

20.10.2016.

23.12.2016.

Kako citirati ovaj rad? / How to cite this article?

Style - APA Sixth Edition:

Jakovljević, S., \& Vujaković, T. K. (2017, January 15). Analiza konkurentnosti Bosne i Hercegovine u kontekstu pristupnih procesa EU. (Z. Cekerevac, Ed.) FBIM Transactions, 5(1), 59-73. doi:10.12709/fbim.05.05.01.06

Style - Chicago Sixteenth Edition:

Jakovljević, Sanja, and Tatjana Klincov Vujaković. "Analiza konkurentnosti Bosne i Hercegovine u kontekstu pristupnih procesa EU." Edited by Zoran Cekerevac. FBIM Transactions (MESTE) 5 , no. 1 (January 2017): 59-73. doi:10.12709/fbim.05.05.01.06.

Style - GOST Name Sort:

Jakovljević Sanja and Vujaković Tatjana Klincov Analiza konkurentnosti Bosne i Hercegovine u kontekstu pristupnih procesa EU [Journal] // FBIM Transactions / ed. Cekerevac Zoran. - Belgrade Toronto : MESTE, January 15, 2017. - 1 : Vol. 5. - pp. 59-73.

Style - Harvard Anglia:

Jakovljević, S. \& Vujaković, T. K., 2017. Analiza konkurentnosti Bosne i Hercegovine u kontekstu pristupnih procesa EU. FBIM Transactions, 15 January, 5(1), pp. 59-73.

Style - ISO 690 Numerical Reference:

Analiza konkurentnosti Bosne i Hercegovine u kontekstu pristupnih procesa EU. Jakovljević, Sanja and Vujaković, Tatjana Klincov. [ed.] Zoran Cekerevac. 1, Belgrade - Toronto : MESTE, January 15, 2017, FBIM Transactions, Vol. 5, pp. 59-73. 